\title{
Three-dimensional cell culture models for investigating human viruses
}

\author{
Bing He, Guomin Chen ${ }^{\bowtie}$, Yi Zeng
}

State Key Laboratory of Infection Disease Prevention and Control, National Institute for Viral Disease Control and Prevention, Chinese Center for Disease Control and Prevention, Beijing 102206, China

Three-dimensional (3D) culture models are physiologically relevant, as they provide reproducible results, experimental flexibility and can be adapted for high-throughput experiments. Moreover, these models bridge the gap between traditional two-dimensional (2D) monolayer cultures and animal models. 3D culture systems have significantly advanced basic cell science and tissue engineering, especially in the fields of cell biology and physiology, stem cell research, regenerative medicine, cancer research, drug discovery, and gene and protein expression studies. In addition, 3D models can provide unique insight into bacteriology, virology, parasitology and host-pathogen interactions. This review summarizes and analyzes recent progress in human virological research with 3D cell culture models. We discuss viral growth, replication, proliferation, infection, virus-host interactions and antiviral drugs in 3D culture models.

\section{KEYWORDS three-dimensional (3D) cell culture models; scaffolds; human viruses}

\section{INTRODUCTION}

Infectious diseases have been major challenges to human health and survival for centuries (Morens et al., 2004). Although, over the years, significant progress has been made in the prevention and control of infectious diseases, pathogenic microbes continue to pose an enormous threat to human health (Heesterbeek et al., 2015). The level of human mortality attributed to infection is $13-15$ million deaths annually (WHO, 2013). In recent years, newly emerging infectious agents have represented a continuing challenge, especially those causing viral diseases, such as H7N9 influenza viruses in 2013 (Lam et al., 2013), the Ebola virus outbreak in 2014 (Team, 2014; Heymann et al., 2015) and the Zika

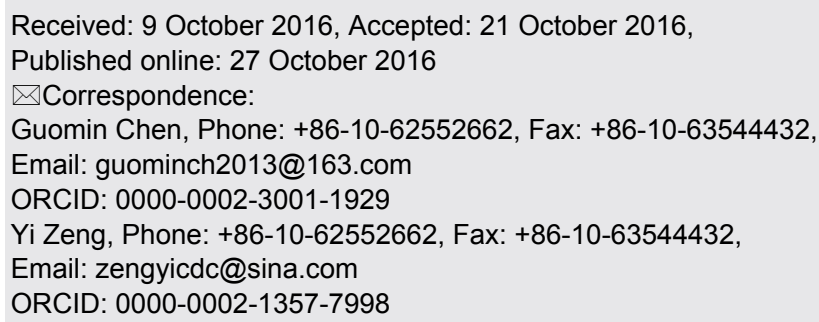

virus outbreak in 2016 (Lessler et al., 2016). Therefore, studying the mechanisms of viral diseases, antiviral agents and vaccines is critical for responding to viral diseases.

Our current understanding of a multitude of human viral diseases and antiviral drugs is based largely on traditional 2D cell Culture, in which cells are grown on glass substrates or flat plastic, such as petri-dishes, multiwell plates and cell culture flasks (Nickerson et al., 2007; Baker and Chen, 2012; Li and Cui, 2014), or on animal model systems. Indeed, 2D cell cultures have contributed tremendously to the investigation of infectious disease etiology, the immune mechanisms used to defend against human viruses (Nickerson et al., 2007; Barrila et al., 2010), and especially the biochemistry and molecular biology of viral replication (Andrei, 2006). However, 2D monolayer culture has significant restrictions in mimicking the physiological complexity of the in vivo microenvironment that is encountered by pathogens; this model cannot accurately reproduce the natural infection process (Barrila et al., 2010). In addition, due to the lack of suitable cell culture models, the study of the life cycle of fastidious viruses and virus-host interactions has been hampered (Lindenbach et al., 2005; Sainz et al., 2009a). 
Furthermore, animal models are costly and their use has ethical issues (Page et al., 2013). A multitude of pathogens are species specific, and the pathogenesis mechanisms cannot be captured by time-consuming animal models (Griffith and Swartz, 2006). As an example, SARS (severe acute respiratory syndrome) in animal models seldom progressed to lethality, however, it may cause death in people (Louz et al., 2013).

To overcome these limitations associated with 2D monolayers and animal models, various types of 3D cell culture models have been developed (Edmondson et al., 2014). 3D cell models bridge the gap between $2 \mathrm{D}$ cell cultures and animal models by providing an in vitro cell model system mimicking more accurately the in vivo microenvironment, which contributes to the understanding of both virus-host interaction and the fundamental mechanisms of human viruses, as well as promoting the development of antiviral drugs. Cells grown on 3D culture systems can differ considerably in their morphology, viability, signaling control, gene expression, differentiation, proliferation and drug sensitivity in comparison with those grown on flat 2D tissue substrates (Friedl et al., 2012; Edmondson et al., 2014; Antoni et al., 2015). For example, Matrigel-cultured Huh7 cells assemble into 3D spheroids, whereas standard 2D-cultured cells form epithelial monolayers (Molina-jimenez et al., 2012). Cells cultured in a 3D matrix can adequately reproduce the function of 3D tissues and mimic cell-cell and cellmatrix interactions in vivo. 3D culture systems have been designed to allow investigation of infectious pathogens, such as human viruses, bacteria and parasites. These models have an invaluable role in virology today.

This review focuses on the recent progress of human virological research with 3D cell culture models, including human viral growth, replication, proliferation, infection, viral life cycle, virus-host interaction and the development of antiviral drugs.

\section{CHARACTERISTICS OF 3D CELL CULTURE}

\section{Matrices/scaffolds for 3D cell culture}

Biomaterials play a pivotal part in tissue engineering and regenerative medicine, and are regarded as a platform that mimics key features of the natural extracellular matrix (ECM) (Lutolf and Hubbell, 2005). In tissue engineering applications, especially in 3D cell cultures, the mechanical and biochemical properties of scaffolds impact on cellular morphogenesis and function (Guilak et al., 2009). Natural and synthetic polymers have been extensively explored in 3D cell cultures; such scaffold materials are designed to support the attachment, maintenance, proliferation and differentiation of cells (Keane and Badylak, 2014). Tissue engineering may provide the pos- sibility of flexibly altering the physical and biochemical characteristics of scaffolds and matrices (Hutmacher, 2010).

\section{Natural polymers}

Currently, the most common 3D scaffolds are naturally derived polymer materials that can be directly extracted from plant, animal or human tissue (Ravi et al., 2015; Worthington et al., 2015), such as collagen, hydrogel, Matrigel, laminin, gelatin, hyaluronate, chitosan, silk, fibrin, etc. (Lee et al., 2008), because they have similar biological properties to ECM and in vivo environments. Natural polymers show good biocompatibility, low toxicity and chronic inflammatory response (Haycock, 2010). In addition, they can also be coupled with adhesion and growth/differentiation factors (Ruedinger et al., 2015). However, natural ECM scaffolds also have their own drawbacks, including the limited source of natural tissues, the uncontrollable process, the unpredictable complexity of the natural organs and the immune responses to stimuli (Zhang et al., 2016).

\section{Synthetic polymers}

In recent years, synthetic polymers have been designed and extensively applied in tissue engineering to substitute for the natural ECM microstructures and properties (Lutolf and Hubbell, 2005), because of their flexible biophysical and biochemical characteristics, high versatility, reproducibility and good workability (Gunatillake and Adhikari, 2003; Xu et al., 2014). Synthetic materials include polystyrene, polycaprolactone, poly(lactic acid), polyethylene glycol (PEG), poly(acrylic acid), polyurethanes, poly(ortho ester) and polyanhydrides, etc. (Lee et al., 2008; Haycock, 2010). Synthetic polymers may have some greater strengths in 3D cell culture compared with natural polymers: they promote cell adhesion, spreading and proliferation (Choi et al., 2015). However, synthetic materials are generally less biocompatible than natural ones and are not bioactive (Haycock, 2010). Recently, considerable progress has been made with the synthetic polymers used in 3D cell culture, and many methods for altering biomaterial activity are currently being developed (Keane and Badylak, 2014).

\section{D versus $2 \mathrm{D}$ cell culture}

$3 \mathrm{D}$ cell culture is an in vitro culture model where different cell types are placed within a carrier composed of different materials with 3D structures, leading to cells that can grow and migrate in $3 \mathrm{D}$ space, further promoting cell proliferation and differentiation, to mimic in vivo cell microenvironments (Antoni et al., 2015). With the dynamic advancements in the instrumentation technology and material sciences (Ravi et al., 2015), increasing $3 \mathrm{D}$ cell culture models are developed for applying in bio- 
logical science. Cells grown in a 3D environment more closely represent normal cellular characteristics and biological function that the traditional 2D monolayer culture cannot provide. For example, cells cultured in a 3D matrix can adequately reproduce the function of 3D tissues and mimic cell-cell and cell-matrix interactions that affect proliferation, differentiation, morphology and a range of cellular functions in vivo, which are lost in conventional 2D conditions (Mazzoleni et al., 2009). The classic polarized patterns of signaling that guide migration in 2D models are not essential for efficient migration in 3D models (Petrie et al., 2012). Almost all cells use lamellipodia to migrate on 2D substrates, however, multiple modes of migration are observed in three dimensions, including lamellipodial, lobopodian, amoeboid migration (Madsen and Sahai, 2010; Petrie et al., 2012) and collective migration (Friedl and Alexander, 2011). Baker and Chen (2012) further discuss examples that $3 \mathrm{D}$ context can provide insights in adhesion, migration and polarization which cannot be provided by the traditional 2D systems. Table 1 shows the differences between $2 \mathrm{D}$ and $3 \mathrm{D}$ cell cultures.

\section{Strengths and weaknesses of 3D models}

3D cell cultures provide a platform for cell proliferation and differentiation. In addition, some emerging 3D culture models can allow nutrients and metabolites to be transported in and out of the 3D cells ( $\mathrm{Li}$ and Cui, 2014). Although current 3D systems provide unique mechanistic insights into cell-microenvironment interaction, most 3D models do not replicate all complex physiological features of real-tissue in vivo. They often lack the normal vasculature, normal transport of small molecules, host immune responses, internal tissue tensions, tissue heterogeneity and fluid flows observed in vivo. In addition, those models cannot precisely replicate biochemical composition, gradients of soluble regulatory factors and other microenvironment factors in vivo (Yamada and Cukierman, 2007; Grinnell and Petroll, 2010; Baker and Chen, 2012; Friedl et al., 2012). Moreover, more complex architectures are found in tissues in vivo, such as orthogonally arranged collagen sheets and collagen fibril bundles. However, the most current methods to prepare 3D fibrillar matrices result in matrices in which fibrils lack any particular organization or become aligned uniaxially (Grinnell and Petroll, 2010). A brief summary of the strengths and limitations of $3 \mathrm{D}$ culture models is presented in Table 2.

\section{TYPES OF 3D CULTURE MODELS APPLICABLE TO HUMAN VIRUSES}

Currently available and typical 3D models are spontaneous cell aggregation, liquid overlay, gyratory rotation and spinner flask spheroid cultures, scaffold-based culture systems, microcarrier beads and the rotary cell culture system (Kim, 2005; Page et al., 2013), as well as 3D perfusion cell culture, microfluidic 3D cell culture and 3D cell culture by magnetic levitation (Souza et al., 2010;

Table 1. The differences of biological function and cellular characteristics in 2D and 3D systems

\begin{tabular}{|c|c|c|c|}
\hline $\begin{array}{l}\text { Cell characteristics/ } \\
\text { function }\end{array}$ & $2 \mathrm{D}$ & $3 \mathrm{D}$ & References \\
\hline Cell shape & Single layer & Multiple layers & Edmondson et al., 2014 \\
\hline Morphology & $\begin{array}{l}\text { Sheet-like flat and stretched cells in } \\
\text { monolayer }\end{array}$ & From aggregate/spheroid structures & Edmondson et al., 2014 \\
\hline Polarity & Partial polarization & $\begin{array}{l}\text { More accurate depiction of cell } \\
\text { polarization }\end{array}$ & Antoni et al., 2015 \\
\hline Stiffness & High stiffness & Low stiffness & Baker and Chen, 2012 \\
\hline Migration & Only one mechanism & Diverse cell migration strategies & $\begin{array}{l}\text { Pampaloni et al., } 2007 \\
\text { Petrie and Yamada, } 2012\end{array}$ \\
\hline Adhesions & $\begin{array}{l}\text { Represent exaggerated stages of } \\
\text { dynamic in vivo }\end{array}$ & $\begin{array}{l}\text { Generate adhesions comparable } \\
\text { with } 3 \mathrm{D} \text { adhesion in vivo }\end{array}$ & Cukierman et al., 2002 \\
\hline Proliferation & $\begin{array}{l}\text { Tumor cells grown in monolayer } \\
\text { faster than in } 3 D \text { spheroids }\end{array}$ & Similar to the situation in vivo & Antoni et al., 2015 \\
\hline $\begin{array}{l}\text { Gene expression/ } \\
\text { protein expression }\end{array}$ & $\begin{array}{l}\text { Often display differential gene/protein } \\
\text { levels compared with in vivo models }\end{array}$ & $\begin{array}{l}\text { Gene and protein expression in vivo } \\
\text { to be present in } 3 D \text { models }\end{array}$ & $\begin{array}{l}\text { Ravi et al., } 2015 \\
\text { Ghosh et al., } 2005\end{array}$ \\
\hline Drug sensitivity & $\begin{array}{l}\text { Cells are more sensitive to drugs in } \\
\text { contrast to } 3 D \text { cells }\end{array}$ & $\begin{array}{l}\text { Cells are more resistant to anticancer } \\
\text { drugs compared with } 2 D \text { cells }\end{array}$ & $\begin{array}{l}\text { Loessner et al., } 2010 \\
\text { Karlsson et al., } 2012\end{array}$ \\
\hline Cell-cell interaction & Limited & In vivo-like & Li and Cui., 2014 \\
\hline
\end{tabular}


Table 2. Strengths and limitations of 3D cell culture models

Strengths

Cells cultured in 3D system can represent a more physiological microenvironment.

As compared with 2D cultures, 3D cell cultures more accurately simulate normal cell morphology, proliferation, migration, cell-cell and cell-ECM interactions.

$3 \mathrm{D}$ cell culture is flexible, cost effective and controllable, as well as a

high-throughput platform.

Several 3D models can monitor and control physiological conditions: temperature, $\mathrm{pH}$, oxygen concentration, metabolites and growth factors.

Limitations

In vivo complex and physiological microenvironment not to be replicated.

Poor reproducibility for some biomimetic scaffolds.

Some available 3D models to be more time and expensive.

Quality of imaging interfering with 3D scaffold size, material transparency and

microscope depth.
References

Vinci et al., 2012

Antoni et al., 2015

Edmondson et al., 2014

Nickerson et al., 2007

Murakami et al., 2008; Li and Cui., 2014;

Worthington et al., 2015

References

Friedl et al., 2012; van Duinen et al., 2015

Antoni et al., 2015

Vinci et al., 2012

Antoni et al., 2015
Li and Cui, 2014; van Duinen et al., 2015). Here, we only focus on those 3D models that have been utilized to study human viruses or will be applicable for this in the future.

\section{Multicellular spheroid (MCS) models}

3D MCS culture has become a valuable tool for mimicking the biological features and functional characteristics of native tissue. MCSs are cells that aggregate and undergo the process of self-assembly on an attachment surface or scaffold. During self-assembly, mono-dispersed cells form 3D microtissues (Achilli et al., 2012; Lee et al., 2015). The spheroid format is particularly useful in cancer research as it enables quick discovery of morphological changes in transformed cells (Antoni et al., 2015). The most commonly used model is the multicellular tumor spheroids model, which has phenotypic characteristics close to those of human tumor tissues. Consequently, it has been applied extensively in reproducing the key elements of malignant tumor behavior (Hamilton, 1998).

Traditional and newer techniques have been investigated for spheroid production. First, the spinner flask method, which prevents cell attachment to the vessel surface and promotes cell-cell contacts via constant stirring. This method is relatively simple and produces massive spheroids, suitable for high-throughput testing, but has a high shear force and variability in cell size/number (Lin and Chang, 2008; Breslin and O'driscoll, 2013). Second, the hanging drop method depends on gravity forces to form spheroids on inverted substrates (Kelm et al., 2003). This method is inexpensive and suitable for highthroughput testing, and the spheroid size can be con- trolled; however, it is labor intensive and mass production is limited (Lin and Chang, 2008). Third, liquid overlay culture, which prevents the attachment of cells to tissue culture plates and promotes spheroid formation (Achilli et al., 2012). Although this method is easy to set up, rapid and makes screening easy, the size and shape of the spheroids are heterogeneous. Fourth, a rotating-wall vessel (RWV) creates a microgravity that supports cells in suspension and promotes cell aggregation into spheroids. This method allows good control of the microenvironment over time (Achilli et al., 2012). In addition, pellet culture 3D scaffolds can also form MCSs, especially with micro-fluidics and the magnetic cell levitation method, which were developed in recent years to create new opportunities to form spheroids (Kim et al., 2013).

MCS models have given rise to many advances in basic cell science, including understanding tumor invasion and migration, and creating models for toxicology testing and drug discovery (Achilli et al., 2012; Vinci et al., 2015). The development of new technologies for analyzing spheroids has led to a rapid increase in their adoption and expansion of their applications. New technologies for analyzing spheroids have led to a rapid increase in their adoption and expansion of their applications.

Apart from those applications mentioned above, MCS models have also been investigated as basic units for human viruses. Although the study of viruses in spheroid models is still limited so far, investigating virus-cancer interactions, the mechanism of viruses causing cancer and evaluating antiviral agents relating to tumors by those models may lead to the future direction in the field of cancer. 
3D cell culture using RWV or radial-flow bioreactor (RFB)

The RWV is an optimized suspension culture vessel for forming 3D tissue-like assemblies (TLAs). The RWV is based on a rotating cylinder that is completely full with culture medium, the sedimentation of cells in the vessel is counterbalanced by the rotating fluid, creating a constant, gentle fall of cells through the medium under conditions of physiologically relevant fluid shear (Hammond and Hammond, 2001; Nickerson et al., 2004; Barrila et al., 2010). To generate 3D cellular aggregates, cells are first cultured in 2D monolayers. When the cells have grown to an appropriate density, they are removed from the petri dishes or flasks and re-suspended in culture medium, then they are placed within porous ECMcoated microcarrier beads for attachment (Barrila et al., 2010). Lastly, the cellular aggregates are harvested and analyzed.

Traditional cell culture and parts of some 3D models may generate high shear forces, which may injure the cells and block proper tissue-specific differentiation (Unsworth and Lelkes, 1998), and inadequate nutrient and oxygenation transfer give rise to cell death, posing critical obstacles to establishing functional 3D culture systems. To overcome these problems, the NASA (National Aeronautics and Space Administration) Johnson Space Center developed the RWV (Goodwin et al., 1992), which provides a low fluid-shear environment and minimal turbulence that promotes cell growth and randomized gravitational vectors (Goodwin et al., 1993). The fluid dynamics of RWV bioreactors allow oxygen and nutrients to diffuse across into the cell aggregates and prevent tissue constructs from necrotic cores (Goodwin et al., 2015).

Studies have shown that the RWV can produce 3D models and can recreate many of the fundamental facets of the real tissue in vivo, such as 3D cellular polarity, cellular differentiation and proliferation, cell-cell interaction, multicellular complexity and functionality (Rhee et al., 2001; Cerwinka et al., 2012; Samuelson and Gerber, 2013). RWV-derived 3D models have been applied to the investigation of infectious agents (viruses, bacteria and parasites) (Barrila et al., 2010). Those models can reflect the natural infection process. The inherent flexibility of this system is an ideal platform for exploring fundamental questions in virology. A multitude of research has shown that RWV-derived models utilizing human cells are a valuable tool for investigating viral growth, replication, viral infection, viral entry, the viability of virions and virus-host interaction (Margolis et al., 1997; Long et al., 1998; Nickerson et al., 2007; Straub et al., 2007; Barrila et al., 2010; Berto et al., 2013; Goodwin et al., 2015). The RWV provides a useful model system for studying human viruses and has the potential for use in developing and screening antiviral drugs, as well as evaluating vaccines.

The other bioreactor used for studying human viruses is the RFB, consisting of a vessel, column and PC monitoring system. It was originally designed for creating artificial liver tissues allowing human liver cells to maintain their morphological characteristics and physiological functions for a relatively long period of time (Kawada et al., 1998; Aizaki et al., 2003). Culture conditions can automatically be controlled. Temperature, $\mathrm{pH}$ and oxygen concentration in the conditioning vessel are continuously monitored by PC and conditioned by mass flow controller (Murakami et al., 2008). The RFB-derived 3D models have mainly been used for hepatitis $\mathrm{C}$ virus (HCV). However, to our knowledge, no research associated with the RFB being used for human viruses has been reported in PubMed since 2008.

\section{Organotypic epithelial raft cultures}

The organotypic epithelial raft culture is an in vitro 3D culture system, where epithelial cells are placed on top of a dermal equivalent and then cultured at the air-liquid interface to full differentiation (Meyers et al., 1992; Andrei, 2006; Fang et al., 2006). Raft cultures are prepared using cells or tissues derived from dispersed primary keratinocytes, explanted epithelial tissue or established cell lines (Andrei et al., 2010). Organotypic raft culture was originally designed to accurately mimic the in vivo morphological and physiological characteristic of the epidermis (Asselineau and Prunieras, 1984; Meyers et al., 1992). This system, forming a stratified and differentiated epithelium, has provided researchers a useful means to investigate epitheliotropic viruses (Chow, 2015). Over the past few years, human papillomavirus (HPV)-host interactions have been demonstrated with these raft cultures similar to those observed in vivo. This system has been a paramount milestone in the study of HPV so far.

\section{Scaffold/matrix-based cultures}

3D scaffold materials are designed to support the attachment, proliferation and differentiation of selected cell populations grown in 3D culture models. Scaffold-based 3D cultures are playing an increasing role in tissue engineering. In recent years, these models have been applied to virology.

Several matrices have been used to investigate human viruses. Among them, the use of Matrigel as a 3D scaffold has shown promise for the study of several viruses. Matrigel, a gelatinous protein mixture, resembles the complex extracellular environment observed for tissues in vitro and produces a thick matrix for $3 \mathrm{D}$ cell culture (Kleinman and Martin, 2005). HCV has been investigated by this 3D model. In addition, the use of Matrigelbased systems for recombinant adenoviruses and Ep- 
stein-Barr virus has begun to capture researchers' attention (Fotheringham and Raab-traub, 2013; Wang et al., 2014). Alginate, including sodium-alginate salt and calcium-alginate, is also used for studying HCV. Mebiol gel, a thermoreversible gelation polymer (TGP), is a synthetic compound that consists of thermo-responsive and hydrophilic polymer blocks. As a 3D scaffold it was proven to be susceptible to HCV replication (Rajalakshmy et al., 2015).

Although the scaffold/matrix-based 3D culture models used for human viruses appear to be very limited so far, these systems may be applied in virology to define new anti-virus strategies, and may also provide a potential platform for the specific design of effective individual therapy according to patient-specific strains (Aly et al., 2009).

\section{Novel 3D cell culture models}

The multicellular complexity of tissues cannot be captured by typical 3D cell culture models, these models lack vasculature, do not provide precise control over gradients and undergo medium exchange at discrete time points instead of in a continuous manner (van Duinen et al., 2015). In recent years, several novel 3D culture models have been developed for further studying human tissue pathophysiology and physiology in vitro. Microfluidic 3D cell culture allows spatial control over fluids in micrometer-sized channels. This model has become a valuable tool to further increase the physiological relevance of $3 \mathrm{D}$ cell culture by enabling spatially controlled co-cultures, perfusion flow and spatial control over signaling gradients. van Duinen et al. (2015) have reviewed the most important progress in microfluidic 3D cell culture since 2012. Using hydrogels in microfluidic systems have been a recent trend, this model offers cells a more physiologically relevant 3D matrix (Huang et al., 2011; Chung et al., 2012). The microfluidics 3D system will play an important role in the development of personalized medicine, especially in the field of cancer. In addition, 3D perfusion cell culture, an emerging technology, may provide a potential research avenue for commercial applications in drug discovery, regenerative medicine and tissue engineering. This model, mimicking the blood circulation in the human body, can control physiological chemostatic conditions, and create gradients of oxygen, growth factors and other biochemical signals. The 3D perfused culture model also can maintain the stability of the local microenvironment of the residing cells by continuously providing a nutrient supply and waste removal (Li and Cui, 2014). Souza et al. (2010) reported a novel 3D tissue culture based on magnetic cells levitation. In this method, cells bind with a magnetic iron oxide nanoparticle assembly comprising gold nanoparticles and cell-adhesive peptide sequences. By spatially controlling the magnetic field, cells are concentrated at the airliquid interface, where they aggregate to form larger 3D cultures (Haisler et al., 2013). The magnetic levitation method (MIM) and other associated techniques (cell culture, imaging and $\mathrm{IHc}$ ) adapted for the MlM are described by Haisler et al.(2013).

Although there are no reports associated with studying human viruses using those models, these approaches may become valuable tools in the field of human viruses in the future. The advantages and disadvantages of different 3D culture models used for human viral growth, replication, proliferation, infection and antiviral drugs are listed in Table 3.

To develop routine and advanced 3D cell culture devices, several factors must be considered, such as the cost of equipment, running cost, throughput and the simple operation. Commercial development of in vitro 3D models and applications has been summarized by $\mathrm{Li}$ and Cui (2014), including the suppliers, the core technology and 3D products. The devices, scaffolds and technical demands for different $3 \mathrm{D}$ cell cultures are listed in Table 4. 3D models are modular, tractable biomedical systems, which will yield great advances in our understanding of biological science. Although some shortcomings have been found in the current 3D systems, 3D cell culture models hold enormous potential for the basic cell science, tissue engineering and infectious pathogens. 3D cell culture is an evolving field and requires further research for its optimization by combining a number of key areas including materials science, cell biology and bioreactor design.

\section{STUDYING HUMAN VIRUSES IN 3D CULTURE SYSTEMS}

\section{Human papillomavirus}

Human papillomavirus (HPV) is small, non-enveloped viruses with a double-stranded DNA genome (Doorbar et al., 2012). More than 180 types of HPV have been identified, which are classified into low-risk and high-risk HPV types (Bernard et al., 2010). The viral genome includes six early proteins E1, E2, E4, E5, E6 and E7, and the late structural proteins L1 and L2 (Malik et al., 2014). High-risk types cause cervical cancers and other anogenital carcinomas (vulvar, vaginal and anal). Types 16 and 18, the two most carcinogenic HPV types, are thought to contribute to $70 \%$ of human cervical cancer (Schiffman et al., 2007).

Organotypic epithelial raft cultures represented a breakthrough in the study of papillomaviruses due to the strict link of HPV replication with epithelial cell differentiation (Andrei et al., 2010). So far, more than nine aspects of HPVs have been explored in these systems. HPV 
Table 3. The advantages and disadvantages of different 3D culture models used for human virology

\begin{tabular}{|c|c|c|c|}
\hline MCS cultures & $\begin{array}{l}\text { High-throughput assay } \\
\text { Best suited for cancer } \\
\text { research } \\
\text { Reproduces tissue-like } \\
\text { organization } \\
\text { Co-culture possible }\end{array}$ & $\begin{array}{l}\text { High shear stress } \\
\text { Size of spheroid limiting } \\
\text { Limited flexibility }\end{array}$ & $\begin{array}{l}\text { Achilli et al., } 2012 \\
\text { Asthana and Kisaalita., } 2012\end{array}$ \\
\hline $\begin{array}{l}\text { 3D cell culture } \\
\text { using RWV }\end{array}$ & $\begin{array}{l}\text { Low fluid-shear environment } \\
\text { Inherent flexibility } \\
\text { Easy manipulation of culture } \\
\text { conditions } \\
\text { Randomized gravitational } \\
\text { vectors }\end{array}$ & $\begin{array}{l}\text { Potential length of time } \\
\text { Expensive }\end{array}$ & $\begin{array}{l}\text { Barrila et al., } 2010 \\
\text { Hjelm et al., } 2010 \\
\text { Unsworth et al., } 1998 \\
\text { Hammond and Hammond, } 2001\end{array}$ \\
\hline $\begin{array}{l}\text { Scaffold/matrix- } \\
\text { based culture }\end{array}$ & $\begin{array}{l}\text { Quiet incorporates growth } \\
\text { factors } \\
\text { Good extracellular support } \\
\text { Easy to set up } \\
\text { Available for co-cultures }\end{array}$ & $\begin{array}{l}\text { Expensive } \\
\text { Limited in removing cells }\end{array}$ & $\begin{array}{l}\text { Kim, } 2005 \\
\text { Breslin and O'Driscoll, } 2013\end{array}$ \\
\hline $\begin{array}{l}\text { Microfluidic 3D } \\
\text { cell culture }\end{array}$ & $\begin{array}{l}\text { The ability to co-culture cells } \\
\text { in a spatially controlled } \\
\text { manner } \\
\text { Generation of and control } \\
\text { over (signaling) gradients } \\
\text { The integration of } \\
\text { perfusion/flow }\end{array}$ & $\begin{array}{l}\text { Expensive special equipment } \\
\text { Requirement for high sensitive } \\
\text { analytical methods } \\
\text { Difficulty to maintain long term } \\
\text { flow stability } \\
\text { The limited size and low } \\
\text { number of cells }\end{array}$ & $\begin{array}{l}\text { van Duinen et al., } 2015 \\
\text { Breslin and O'Driscoll, } 2013 \\
\text { Li and Cui, } 2014\end{array}$ \\
\hline $\begin{array}{l}\text { 3D cell culture by } \\
\text { magnetic levitation }\end{array}$ & $\begin{array}{l}\text { Does not induce an } \\
\text { inflammatory response by } \\
\text { the cultured cells } \\
\text { Nontoxic } \\
\text { Suitable for co-culture } \\
\text { Simple, flexible and effective }\end{array}$ & Expensive & $\begin{array}{l}\text { Souza et al., } 2010 \\
\text { Tseng et al., } 2013\end{array}$ \\
\hline
\end{tabular}

cannot be propagated in $2 \mathrm{D}$ cell monolayer cultures, so organotypic epithelial raft cultures that generate a stratified and differentiated epithelium have been applied in studying the HPV life cycle (Chow, 2015). The organotypic raft culture system has allowed the study of the en- tire differentiation-dependent life cycle of HPVs, including virion morphogenesis (Mclaughlin-Drubin et al., 2003; Mclaughlin-Drubin and Meyers, 2005). Fang et al. (2006) demonstrated episomal maintenance of HPV-11 DNA in N-Tert cells. HPV-11 episomal DNA-contain- 
Table 4. Devices, scaffolds and technical demands for different 3D cell culture

\begin{tabular}{|c|c|c|}
\hline 3D models & Devices, scaffolds, technical demands & References \\
\hline MCS cultures & $\begin{array}{l}\text { Microfluidics } \\
\text { Hanging drop } \\
\text { Pellet culture } \\
\text { Spinner flask culture } \\
\text { Liquid overlay culture } \\
\text { Rotating-wall-vessel bioreactors }\end{array}$ & $\begin{array}{l}\text { Lin and Chang, } 2008 \\
\text { Kelm et al., } 2003 \\
\text { Achilli et al., } 2012\end{array}$ \\
\hline $\begin{array}{l}\text { 3D cell culture using } \\
\text { RWV }\end{array}$ & Rotating-wall-vessel bioreactors & Antoni et al., 2015 \\
\hline $\begin{array}{l}\text { Organotypic epithelial } \\
\text { raft cultures }\end{array}$ & $\begin{array}{l}\text { The dermal equivalent is composed of natural dermal elements } \\
\text { (collagen matrix with fibroblasts) or a synthetic dermal matrix } \\
\text { maintained on a rigid support }\end{array}$ & $\begin{array}{l}\text { Fang et al., } 2006 \\
\text { Andrei et al., } 2010\end{array}$ \\
\hline $\begin{array}{l}\text { Scaffold/matrix- } \\
\text { based culture }\end{array}$ & $\begin{array}{l}\text { Natural polymers: such as hydrogel, collagen, Matrigel, laminin, } \\
\text { gelatin, hyaluronate, chitosan } \\
\text { Synthetic polymers: such as polycaprolactone, polyethylene glycol, } \\
\text { polyurethanes and polyanhydrides }\end{array}$ & $\begin{array}{l}\text { Lee et al., } 2008 \\
\text { Haycock, } 2010\end{array}$ \\
\hline $\begin{array}{l}\text { Microfluidic 3D cell } \\
\text { culture }\end{array}$ & $\begin{array}{l}\text { Cell patterning inside a hydrogel, exploiting the microfluidic properties } \\
\text { and differences in viscosity and pressure } \\
96 \text { microfluidic culture chambers integrated underneath a microtiter } \\
\text { plate Microfluidic hanging drop network } \\
\text { Dynamically perfused chip-based bioreactor platform }\end{array}$ & $\begin{array}{l}\text { Bischel et al., } 2013 \\
\text { Frey et al., } 2014 \\
\text { Atac et al., } 2013 \\
\text { Trietsch et al., } 2013 \\
\text { van Duinen et al., } 2015\end{array}$ \\
\hline $\begin{array}{l}\text { 3D perfusion } \\
\text { cell culture }\end{array}$ & $\begin{array}{l}\text { Stirred-suspension culture reactors } \\
\text { Rotating-wall-vessel bioreactors } \\
\text { Hollow fiber bioreactors } \\
\text { Direct perfusion bioreactors }\end{array}$ & $\begin{array}{l}\text { Jasmund and Bader, } 2002 \\
\text { Martin and Vermette, } 2005 \\
\text { Morin et al., } 2003 \\
\text { Zhao and Ma, } 2005 \\
\text { Li and Cui, } 2014\end{array}$ \\
\hline $\begin{array}{l}\text { 3D cell culture by } \\
\text { magnetic levitation }\end{array}$ & $\begin{array}{l}\text { Consisting of gold nanoparticles, magnetic iron oxide nanoparticles } \\
\text { and filamentous bacteriophage }\end{array}$ & $\begin{array}{l}\text { Souza et al., } 2010 \\
\text { Haisler et al., } 2013\end{array}$ \\
\hline
\end{tabular}

ing cell populations grown in raft culture showed induction of a productive viral life cycle. This system has served as a faithful in vitro model for investigating propagation, infection and neutralization of HPVs, as well as producing infectious HPV virions (Ozbun, 2002; MclaughlinDrubin et al., 2004; Chow et al., 2009; Wang et al., 2009). Examinations of virus-host interactions have also been reported (Anacker and Moody, 2012). Several researchers have further used the organotypic epithelial raft cultures to study the interaction of HPV with other epitheliotropic viruses, such as herpes simplex virus (HSV) and HPVs, adeno-associated virus and HPV interaction (Meyers et al., 2003; Hermonat et al., 2005). Importantly, Meyers et al. (2002) demonstrated that the nonstructural genes of HPV18 functionally interact with the structural genes of HPV16, allowing the complete HPV life cycle to occur, which is the first report of the propagation of chimeric HPV by normal life cycle pathways. Screening and evaluating antiviral compounds can also be carried out with raft cultures (Satsuka et al., 2010). Recently, research on the relationship between tumor progression and HPV is increasing, which will hopefully lead to the development of effective treatments for HPV-associated cancer.

A detailed review concerning evaluation of the efficacy of the therapeutic interventions for HPV using epithelial raft cultures has been published by Andrei et al. (2010). So far, these studies appear to be rather limited. In recent years, an increasing number of studies have addressed more specifically the role of HPV gene products and the difference in protein function between different HPV types, as well as the mechanisms of HPV carcinogenesis, especially the relationship between HPV oncoproteins (E2, E4, E5) and cervical tumors (Doorbar, 2016). The effects of HPV16 E5 deletion mutants on epithelial morphology have been reported by Barbaresi et al. (2010). Mole et al. (2009) using the organotypic raft culture with epithelial cells, demonstrated that SF2/ASF 
(splicing factor 2/alternative splicing factor) is up-regulated in response to differentiation in HPV-infected cervical epithelial raft tissue. A specific subset of SR proteins (Ser-Arg rich proteins) regulated by HPV16 E2, including SF2/ASF, SRp20 and SC35, were also overexpressed during cervical tumor progression. Furthermore, organotypic raft cultures using verruciformis-derived keratinocytes could be used to reconstruct the $\beta$-HPV life cycle and show the relationship between $\beta$-HPV E4 expression patterns and disease severity. This finding is indicative that $\mathrm{E} 4$ may be a possible marker of viral expression during $\beta$-HPV-associated skin cancer progression (Borgogna et al., 2012). A longitudinal cell culture using organotypic raft cultures has been used to investigate the immortalizing and transforming abilities of naturally occurring E6 variants in primary human foreskin keratinocytes (PHFKs). The observations provided insight into the mechanisms behind how PHFKs are immortalized and transformed into malignant tumors by the viral oncoproteins of HPV16 (Richard et al., 2010). In addition, a breakthrough in HPV chimeric genomes producing infectious virus in organotypic raft cultures was achieved. Researchers constructed HPV18 chimeric genomes in which the HPV18 capsid genes were replaced with those of evolutionarily diverse PV types, including HPV45, HPV39, HPV33, HPV31, HPV11, HPV6b, HPV1a, CRPV and BPV1. Each of the chimeric genomes generated infectious viral particles in organotypic raft cultures (Bowser et al., 2011).

\section{Human immunodeficiency virus}

Human immunodeficiency virus (HIV), originally isolated from a patient with acquired immune deficiency syndrome (AIDS) in France in 1983 (Barre-Sinoussi et al., 1983), is a major contributor to the global burden of disease. Although dramatic progress has been made in the development of novel antiviral drugs (De Clercq, 2007), an effective vaccine remains elusive despite two decades of effort (Maartens et al., 2014).

The use of antiretroviral drugs has markedly reduced the mortality rate amongst AIDS patients. However, the effect of these drugs on oral epithelium growth and differentiation is presently unknown. A new 3D cell culture system, organotypic raft cultures of gingival keratinocytes, has been established. Research demonstrated that HIV protease inhibitor amprenavir severely inhibited the growth of gingival epithelium cultured in this model. When the drug was added at day 8 , amprenavir treatments altered the proliferation and differentiation of gingival keratinocytes (Israr et al., 2010). There are several other studies that have reported similar results utilizing organotypic raft cultures of gingival keratinocytes to investigate the effect of anti-HIV drugs on gingival epithelium growth and differentiation. Those drugs included protease inhibitor lopinavir/ritonavir, and nucleoside reverse transcriptase inhibitors zidovudine, efavirenz and tenofovir (Israr et al., 2011; Mitchell et al., 2012; Mitchell et al., 2014). Furthermore, Balzarini et al. (2013) developed a multi-targeted drug, 6-phosphonylmethoxyethoxy-2, 4-diaminopyrimidine (PMEODAPym), and demonstrated that this drug efficiently suppressed both HIV-1 and HSV-2 in organotypic epithelial raft cultures of primary human keratinocytes. In addition, 3D cell cultures could be developed as a potential model for studying the neuropathogenesis of HIV infection and the development of drug candidates that could effectively treat the neurological complications of HIV infection (Nickerson et al., 2007). Investigating the effects of highly active antiretroviral therapy (HAART) and designing multi-targeted antiviral drugs that could effectively suppress both HIV and hepatitis B virus (HBV) (or HCV) may lead to the future direction of HIV in $3 \mathrm{D}$ culture systems.

\section{Hepatitis C virus}

Hepatitis C virus (HCV), first identified in 1989, poses an enormous threat to public health and affects more than 170 million people around the world (Choo et al., 1989; Poynard et al., 2003; Cox, 2015). Although the 2D cell culture model has been the standard tool for investigating $\mathrm{HCV}$ in cell culture, the $\mathrm{HCV}$ life cycle in vivo occurs in a much more complex environment compared to that in standard 2D cultures. 3D cell culture models can more closely mimic the polarized and differentiated state of hepatocytes in vivo (Liu et al., 2014). So far, $\mathrm{HCV}$-associated research has been reported in three independent 3D cell cultures systems: 3D/RFB, 3D RWV bioreactors and the scaffold/ matrix-based 3D cultures.

Differentiated human hepatoma FLC4 cells transfected with full-length HCV RNA can produce and secrete infectious particles in the 3D RFB culture system (Aizaki et al., 2003). A similar result has been found in the RFB system following transfection of FLC4 cells with a dicistronic HCV genome derived from genotype $1 \mathrm{~b}$, as well as in the 3D/TGP system using Huh-7 cells (Murakami et al., 2006). Furthermore, research has demonstrated that a long-term culture of the $3 \mathrm{D}$ RFB system provides a potential platform for investigating $\mathrm{HCV}$ dynamics, as well as examining the therapeutic effects of interferon alpha in this 3D culture model (Murakami et al., 2008).

Although HCV culture infection models based on the HCV JFH-1 molecule clone and Huh-7 cells permit the production of virus, these recombinant HCV genomes only proliferate in sub-lines of Huh-7 cells, which do not allow infection or proliferation of blood-borne HCV. A novel in vitro culture system combining 3D/TGP and immortalized human hepatocytes (Hus-E/2 cells) demonstrated efficient support of the infection and replication 
of natural HCV (Aly et al., 2009). Moreover, another system based on a 3D hollow fiber culture system and the Hus-E/2 cell line was used for investigating the life cycle of blood-borne $\mathrm{HCV}$, this 3D infection system allowed the reproduction of strain-dependent events reflecting virus-cell interactions and viral dynamics (Aly et al., 2009).

More recently, HCV infection, replication and life cycle have been studied frequently. RWV-cultured Huh7 cells form complex, multilayered 3D aggregates, highly permitted for $\mathrm{HCV}$ infection, which provides a platform for studying HCV biology and the interaction between HCV infection and host cell function (Sainz et al., 2009b). Cho et al. (2009) described that Huh-7.5 cells cultured in a 3D PEG-based hydrogel system can be efficiently infected with $\mathrm{HCV}$, which was the first report of de novo infection with the virus (both replication-defective pseudovirus particles and fully infectious HCV). In addition, Matrigel-embedded 3D culture of Huh-7 cells or Huh-7.5 cells was used as a hepatocyte-like polarized system and supported HCV infection by JFH-1 virus, as well as producing infective viral particles (Molina-jimenez et al., 2012; Liu et al., 2014). Researchers succeeded in reconstituting a hepatic-like structure formation from Huh-7 cells using a calcium-alginate encapsulation model, which provides an opportunity for viral studies, especially for application with HCV (Tran et al., 2013). Recently, Mebiolgel-derived 3D culture models were shown to support cell growth as $3 \mathrm{D}$ spheroids for up to 63 days, this system was susceptible to HCV infection and replication; it could be implemented as an alternate for primary hepatocytes in studies such as viral isolation from patient serum (Rajalakshmy et al., 2015).

So far, many facets of HCV have been extensively studied in 3D cell culture systems. However, knowledge of several dimensions of $\mathrm{HCV}$ are still limited: (i) $\mathrm{HCV}$ biology, (ii) anti-HCV therapeutics, (iii) HCV-HIV interaction and (iv) HCV-cancer interaction. More efforts must be taken to further research HCV. 3D culture systems will provide insight into the biophysical properties and viral morphogenesis of HCV particles and assessing anti-HCV compounds. This system may have advantages in studying aspects of HCV biology, such as viral assembly and budding, and also provides a system for screening antiviral drugs that inhibit the release or transmission of infectious HCV (Liu et al., 2014).

\section{Hepatitis E virus}

Hepatitis E virus (HEV) was discovered during the Soviet occupation of Afghanistan in the 1980s. Anti-HEV therapy has been successfully used in chronic hepatitis E, the first vaccine available for clinical use is licensed in China (Mihalcin et al., 2015).

At present, the life cycle of HEV is still poorly under- stood, extensive study of the viral replication cycle has been hampered by the lack of efficient cell culture systems and animal models (Osterman et al., 2015). Research demonstrated that HEV can replicate efficiently in human hepatoblastoma PLC/PRF/5 cells cultured in a RWV for up to 5 months, HEV nucleic acid was detected by reverse transcription-PCR in the supernatant of the infected cells in the 3D cell culture system. In contrast, that was not observed in the 2D monolayer system. Complete virions were detection by electron microscopy. However, the study of HEV using 3D systems is limited so far, and $3 \mathrm{D}$ cultures will offer a potential platform for in vitro cultivation of $\mathrm{HEV}$ and investigation of the biology of HEV, as well as the viability of HEV in pig and other environmental samples (Berto et al., 2013).

\section{Human herpes virus}

Human herpes virus (HSV) is a significant pathogen and responsible for a variety of disorders (Nicoll et al., 2012). HSV-1 and HSV-2 are ubiquitous human pathogens. HSV-1 is normally associated with orofacial infections and encephalitis, whereas HSV-2 usually causes genital infections.

More culture models have been applied to epithelial cells for researching HSV. The organotypic raft culture system, which accurately mimics the in vivo physiology of the epidermis, is a most powerful tool for studying infectious agents that infect the epithelium. The first report about the application of 3D organotypic raft culture for the study of HSV appeared in 1996 (Syrjanen et al., 1996). Researchers demonstrated that the F strain of HSV-1 had the ability to produce lytic or nonproductive infection in $\mathrm{HaCaT}$ cells (immortalized skin keratinocytes) cultured in a $3 \mathrm{D}$ organotypic tissue culture. The cultures were infected with HSV-1 (5 PFU) 30 min after the lifting of the epithelial cells into the air-liquid interface and were collected 1 week after inoculation. These cultures were positive for HSV DNA using PCR. One year later, another research study focused on utilizing the organotypic tissue culture methodology for the study of the infection, replication and spread of HSV-1 in fully stratified and differentiated human epithelial tissue (Visalli et al., 1997). A similar HSV-1 culture system has also been described by Hukkanen et al. (1999). They reported HSV-1 could infect immortalized $\mathrm{HaCaT}$ keratinocytes cultured in an organotypic raft culture system, the virus yield was highest when the inoculation took place $72 \mathrm{~h}$ after seeding. In addition, 3D epithelial raft culture represents a novel model for the study of antiviral agents active against HSV. Researchers have shown that specific compounds, such as foscarnet and cidofovir, can reduce the replication and spread of HSV in raft cultures of human keratinocytes (Andrei et al., 2005).

So far, significant advances are still limited in our knowl- 
edge of HSV using 3D culture systems. Anti-HSV may be the future research direction, especially for evaluation of the efficacy of new anti-HSV antivirals before clinical trials.

\section{Varicella-zoster virus}

Varicella-zoster virus (VZV) is a neurotropic human alphaherpesvirus that causes varicella (chicken pox) and herpes zoster (shingles), establishes latency in multiple ganglionic neurons after primary infection and can reactivate to cause zoster (Arvin, 1996; Heininger and Seward, 2006). Unfortunately, investigating VZV pathogenesis is challenging as VZV is strictly a human pathogen and infection is highly restricted in other species. In addition, few culture models are available for studying the interaction between VZV and human neurons, because the life span of terminally differentiated human neurons in culture is short (Goodwin et al., 2013; Zerboni et al., 2014).

The organotypic raft culture model has been applied in studying VZV. As keratinocytes are the main target cells for productive infection in vivo for $\mathrm{VZV}$, characterization of viral replication in organotypic raft cultures of these cells represents a very relevant model for studying virus-host cell interactions and antiviral agents (Andrei et al., 2005). Researchers have reported that they studied the action of antiviral compounds against VZV in organotypic epithelial raft cultures. The cultures were infected by VZV after 4 to 5 days of human keratinocyte differentiation and treated with serial dilutions of antiviral compounds. The antiviral effects were quantified by determining the viral DNA load by real-time PCR for VZV. Furthermore, this system could be very useful for the study of the interactions between viruses and the skin. The raft cultures have been used as a novel approach for investigating VZV replication in epidermal cells undergoing differentiation (Andrei et al., 2005). Similar research has been described by Mcguigan et al. (2007). Recently, a 3D model of normal human neural progenitor (NHNP) cells in TLAs was used to investigate VZV infection. These cells could be effectively cultured for more than 6 months in 3D culture, and exhibited an expression profile similar to that of human trigeminal ganglia. VZV produced a persistent infection in NHNP cell TLAs, which could be maintained for at least 3 months. This $3 \mathrm{D}$ culture system is likely to contribute to deciphering the establishment of VZV latency and reactivation in future studies (Goodwin et al., 2015). Despite advances having been made in understanding VZV-host interactions, numerous questions relating to VZV pathogenesis remain unresolved (Zerboni et al., 2014). 3D culture systems have the potential to provide new approaches for preventing and treating VZV infections, in particular they may provide the cell system required for the generation of high-titer, cell-free attenuated virus for vaccine production.

\section{Adenovirus}

Adenovirus (AdV) is a mildly pathogenic human virus that propagates prolifically in epithelial cells. AdVs have been increasingly used as vectors for gene transfer in tumor cells or as oncolytic viruses (Grill et al., 2002). However, because of incomplete knowledge of the complex virus-cell interactions, the predicted replication selectivity has not been realized. In addition, rodent cells do not allow the complete lytic cycle of human adenovirus (Alemany et al., 2000). Furthermore, specific constraints to adenovirus distribution and spread cannot be studied in cell cultures.

MCSs have been applied in studying the interaction between tumor and adenoviruses. Grill et al. (2002) reported that replication-defective adenoviruses do not penetrate into spheroids; in addition, they described the propagation of replication-competent adenoviruses in spheroids. Organotypic spheroids may provide a useful tool for studying the spread, oncolysis and distribution of adenoviruses. The adenovirus infection process was reproduced in organotypic raft cultures of primary human keratinocytes (Noya et al., 2003). Adenovirus mutants have been found to replicate and promote the killing of cells expressing HPV E6 and E7 oncoproteins, which were present in an organotypic model of human stratified squamous epithelium derived from primary keratinocytes (Balague et al., 2001). More recently, research has demonstrated that adenoviruses could effectively deliver transgenes into the cultured 3D "mini-gut" organoids using adenoviral vectors that expressed fluorescent proteins. The transgene expression could be maintained for at least 10 days. These results were indicative that adenovirus vectors should be explored as effective gene delivery vehicles to introduce genetic manipulations in $3 \mathrm{D}$ organoids (Wang et al., 2014).

\section{Norovirus}

Norwalk virus was first discovered in 1972 (Kapikian et al., 1972) and renamed as norovirus ( $\mathrm{NoV}$ ) in 2002 . NoV is a human enteric pathogen causing epidemic foodborne gastroenteritis (Tan and Jiang, 2014). The major barrier to the research and development of effective interventions for NoV has been the lack of a robust and reproducible in vitro cultivation system (Robinson and Pfeiffer, 2014; Ettayebi et al., 2016).

Straub et al. (2007) first developed a 3D culture model with human embryonic intestinal epithelial cells cultured on collagen-I porous microcarrier beads, which were infected by genogroup I and II human NoVs. The results showed that this model could support the natural growth of human NoVs. However, other investigators reported that using these same methods had not been suc- 
cessful. In 2011, Straub et al. (2011) designed another 3D culture model using gastrointestinal epithelial cells (Caco-2); the norovirus viral RNA copy number was significantly increased $\left(>2 \log _{10}\right)$ in this $3 \mathrm{D}$ Caco-2 cell culture system. The results showed that this model supported norovirus replication. However, Papafragkou et al. (2014) reported that using the 3D cell culture model with Caco-2 cells was not suitable for the replication of norovirus. At present, there is still dispute about $3 \mathrm{D}$ culture models for studying NoVs. Further research efforts need to be made in the future.

\section{Other viruses}

Apart from those viruses reviewed above, the use of 3D culture models for other viruses is currently receiving widespread attention. For example, 3D porcine epithelial cell cultures were designed to help understand the interaction between foot-and-mouth disease virus (FMDV) and porcine mucosal epithelial cells. The results demonstrated that FMDV replicated only transiently without any visible cytopathic effect, and infectious progeny virus could be recovered only from the apical side (Dash et al., 2010). Researchers reported that a panel of clinical human rhinovirus (HRV) species $\mathrm{C}$ specimens, including HRV-C2, HRV-C7, HRV-C12, HRV-C15 and HRV-C29 types, were all capable of mediating productive infection in reconstituted 3D human primary upper airway epithelial tissues, and that the virions entered and exited preferentially through the apical surface. This model is considered as a potential tool for modeling the respirat-

Table 5. Studies of human viruses using 3D cell culture models

\begin{tabular}{|c|c|c|c|c|}
\hline Viruses & 3D models & Cell types & Application in virology & References \\
\hline$\overline{\mathrm{HPV}}$ & Organotypic raft cultures & $\begin{array}{l}\text { Primary human } \\
\text { keratinocytes }\end{array}$ & $\begin{array}{l}\text { HPV-cancer/other virus } \\
\text { interaction } \\
\text { HPV propagation and } \\
\text { infection } \\
\text { HPV life cycle } \\
\text { Evaluating the efficacy of } \\
\text { HPV therapy }\end{array}$ & $\begin{array}{l}\text { Mole et al., } 2009 \\
\text { Fang et al., } 2006 \\
\text { Andrei et al., } 2010\end{array}$ \\
\hline HIV & Organotypic raft cultures & $\begin{array}{l}\text { Gingival keratinocytes } \\
\text { Primary human } \\
\text { keratinocytes }\end{array}$ & $\begin{array}{l}\text { Effect of antiretroviral drugs } \\
\text { on primary gingival } \\
\text { epithelium } \\
\text { Evaluation of multi-targeted } \\
\text { drugs }\end{array}$ & $\begin{array}{l}\text { Israr et al., } 2010 \\
\text { Balzarini et al., } 2013\end{array}$ \\
\hline $\mathrm{HCV}$ & $\begin{array}{l}\text { 3D/RFB } \\
\text { 3D/RWV } \\
\text { Scaffold-based 3D cultures }\end{array}$ & $\begin{array}{l}\text { FLC4 cells } \\
\text { Huh-7 cells } \\
\text { HuS-E/2 cell/ Huh- } 7.5 \text { cells }\end{array}$ & $\begin{array}{l}\mathrm{HCV} \text { replication and infection } \\
\text { The life cycle of HCV } \\
\text { Evaluation of anti-HCV drugs }\end{array}$ & $\begin{array}{l}\text { Murakami et al., } 2008 \\
\text { Sainz et al., } 2009 \\
\text { Aly et al., } 2009\end{array}$ \\
\hline HEV & RWV bioreactors & PLC/PRF/5 cells & $\begin{array}{l}\text { The viability of virions } \\
\text { HEV replication }\end{array}$ & Berto et al., 2013 \\
\hline HSV & Organotypic raft cultures & $\begin{array}{l}\text { Immortalized HaCaT } \\
\text { keratin-ocytes } \\
\text { Human keratinocytes } \\
\text { Primary human } \\
\text { keratinocytes }\end{array}$ & $\begin{array}{l}\text { HSV-1 infection, replication } \\
\text { and spread } \\
\text { Study of antiviral agents }\end{array}$ & $\begin{array}{l}\text { Hukkanen, } 1999 \\
\text { Visalli et al., } 1997 \\
\text { Balzarini et al., } 2013\end{array}$ \\
\hline VZV & $\begin{array}{l}\text { Organotypic raft cultures } \\
\text { Tissue-like assemblies } \\
\text { models using RWV bioreactor }\end{array}$ & $\begin{array}{l}\text { Primary human } \\
\text { keratinocytes } \\
\text { Human neural } \\
\text { progenitor cells }\end{array}$ & $\begin{array}{l}\text { Evaluation of antiviral } \\
\text { compounds } \\
\text { VZV infection }\end{array}$ & $\begin{array}{l}\text { Andrei et al., } 2005 \\
\text { Goodwin et al., } 2013\end{array}$ \\
\hline AdV & $\begin{array}{l}\text { Multicellular spheroid model } \\
\text { Organotypic raft cultures } \\
\text { 3D organoids }\end{array}$ & $\begin{array}{l}\text { Primary human } \\
\text { keratinocytes } \\
\text { HEK-293 cells }\end{array}$ & $\begin{array}{l}\text { Adenovirus mutants } \\
\text { Adenovirus vectors }\end{array}$ & $\begin{array}{l}\text { Noya et al., } 2003 \\
\text { Wang et al., } 2014\end{array}$ \\
\hline NoV & RWV bioreactors & $\begin{array}{l}\text { Int- } 407 \text { cells } \\
\text { Caco- } 2 \text { cells }\end{array}$ & Virus replication & $\begin{array}{l}\text { Straub et al., } 2007 \\
\text { Straub et al., } 2011\end{array}$ \\
\hline
\end{tabular}


ory epithelium in the study of infections caused not only by HRVs, but also by other respiratory pathogens (Tapparel et al., 2013). In addition, 3D human intestinal enteroid cultures were designed as a novel pathophysiological model for studying human rotavirus infection, host restriction and pathophysiology (Saxena et al., 2015). Furthermore, Lam et al. (2012) demonstrated a method for measuring the impact of infection on the mechanics of a 3D model of connective tissue using human cytomegalovirus. Table 5 shows some information on human virology in $3 \mathrm{D}$ cell cultures.

\section{FUTURE DIRECTIONS}

3D cell cultures are emerging technologies that can reproduce specific morphological and biochemical features of human cells similar to those found in vivo. Recent progress in the imaging of 3D dynamics may promote the development of $3 \mathrm{D}$ cell culture. $3 \mathrm{D}$ culture models provide a potential tool for studying viral growth, infection, pathogenesis, and virus-host interaction. These culture systems have allowed a breakthrough in the cultivation of fastidious viral pathogens, which has advanced our understanding of the molecular and cellular mechanisms that underlie pathogenic processes in both the virus and host (Barrila et al., 2010). In addition, these models will play a key role in preclinical drug and therapeutic discovery.

It is estimated that $10 \%-15 \%$ of human cancers worldwide are caused by seven human viruses (Moore and Chang, 2010). As an example, high-risk HPV causes cervical cancer, Kaposi's sarcoma herpesvirus leads to Kaposi's sarcoma and HBV contributes to hepatocellular carcinoma. However, the understanding of the relationship between human viruses and tumors is still limited, especially the therapy strategies. 3D cell culture models, capturing tumor complexity in vitro, provide a potentially powerful physical tool for investigating virus-cancer interaction and evaluating antiviral agents. In addition, analyzing the mechanism of human tumor virology in $3 \mathrm{D}$ in vitro may be useful for predicting cancer progress. So far, although the development and testing of viral vaccine in $3 \mathrm{D}$ culture systems is limited, these models may be useful as an alternative means for evaluating preclinical vaccines in the future. Moreover, 3D co-culture holds enormous potential for studying virus-virus interactions (such as HSV and HPV), and for developing novel products for the prevention, diagnosis and treatment of viral disease. In recent years, the development of multi-targeted drugs for suppressing two or more viruses has been receiving widespread attention. It might also be possible to use 3D models for the specific design of effective individual therapy according to patient-specific strains. Most importantly, 3D culture systems may be used not only in future virological studies, but also in more tissue engineering. We expect that these novel, easily made and reliable models will make a contribution to the further understanding of biological science.

\section{ACKNOWLEDGMENTS}

This research was supported by the National Megaprojects for Infectious Diseases (2014ZX10004002-004001).

\section{COMPLIANCE WITH ETHICS GUIDELINES}

The authors declare that they have no conflict of interests. This article does not contain any studies with human or animal subjects performed by any of the authors.

\section{REFERENCES}

Achilli TM, Meyer J, Morgan JR. 2012. Advances in the formation, use and understanding of multi-cellular spheroids. Expert Opin Biol Ther, 12: 1347-1360.

Aizaki H, Nagamori S, Matsuda M, Kawakami H, Hashimoto O, Ishiko H, Kawada M, Matsuura T, Hasumura S, Matsuura Y, Suzuki T, Miyamura T. 2003. Production and release of infectious hepatitis $\mathrm{C}$ virus from human liver cell cultures in the three-dimensional radial-flow bioreactor. Virology, 314: 16-25.

Alemany R, Balague C, Curiel DT. 2000. Replicative adenoviruses for cancer therapy. Nat Biotechnol, 18: 723-727.

Aly HH, Shimotohno K, Hijikata M. 2009. 3D cultured immortalized human hepatocytes useful to develop drugs for blood-borne HCV. Biochem Biophys Res Commun, 379: 330-334.

Anacker D, Moody C. 2012. Generation of organotypic raft cultures from primary human keratinocytes. J Vis Exp, 60:1-4

Andrei G. 2006. Three-dimensional culture models for human viral diseases and antiviral drug development. Antiviral Res, 71: 96-107.

Andrei G, Duraffour S, Van den Oord J, Snoeck R. 2010. Epithelial raft cultures for investigations of virus growth, pathogenesis and efficacy of antiviral agents. Antiviral Res, 85: 431-449.

Andrei G, van den Oord J, Fiten P, Opdenakker G, De WolfPeeters C, De Clercq E, Snoeck R. 2005. Organotypic epithelial raft cultures as a model for evaluating compounds against alphaherpesviruses. Antimicrob Agents Chemother, 49: 46714680.

Antoni D, Burckel H, Josset E, Noel G. 2015. Three-dimensional cell culture: a breakthrough in vivo. Int J Mol Sci, 16: $5517-$ 5527.

Arvin AM. 1996. Varicella-zoster virus. Clin Microbiol Rev, 9: 361381.

Asselineau D, Prunieras M. 1984. Reconstruction of 'simplified' skin: control of fabrication. Br J Dermatol, 111 Suppl 27: 219-222.

Asthana A, Kisaalita WS. 2012. Microtissue size and hypoxia in HTS with 3D cultures. Drug Discov Today, 17: 810-817.

Atac B, Wagner I, Horland R, Lauster R, Marx U, Tonevitsky AG, Azar RP, Lindner G. 2013. Skin and hair on-a-chip: in vitro skin models versus ex vivo tissue maintenance with dynamic perfusion. Lab Chip, 13: 3555-3561.

Baker BM, Chen CS. 2012. Deconstructing the third dimension: 
how $3 \mathrm{D}$ culture microenvironments alter cellular cues. J Cell Sci, 125: 3015-3024.

Balague C, Noya F, Alemany R, Chow LT, Curiel DT. 2001. Human papillomavirus E6E7-mediated adenovirus cell killing: selectivity of mutant adenovirus replication in organotypic cultures of human keratinocytes. J Virol, 75: 7602-7611.

Balzarini J, Andrei G, Balestra E, Huskens D, Vanpouille C, Introini A, Zicari S, Liekens S, Snoeck R, Holy A, Perno CF, Margolis L, Schols D. 2013. A multi-targeted drug candidate with dual anti-HIV and anti-HSV activity. PLoS Pathog, 9: e1003456.

Barbaresi S, Cortese MS, Quinn J, Ashrafi GH, Graham SV, Campo MS. 2010. Effects of human papillomavirus type 16 E5 deletion mutants on epithelial morphology: functional characterization of each transmembrane domain. J Gen Virol, 91: 521-530.

Barre-Sinoussi F, Chermann JC, Rey F, Nugeyre MT, Chamaret S, Gruest J, Dauguet C, Axler-Blin C, Vezinet-Brun F, Rouzioux C, Rozenbaum W, Montagnier L. 1983. Isolation of a T-lymphotropic retrovirus from a patient at risk for acquired immune deficiency syndrome (AIDS). Science, 220: 868-871.

Barrila J, Radtke AL, Crabbe A, Sarker SF, Herbst-Kralovetz MM, Ott CM, Nickerson CA. 2010. Organotypic 3D cell culture models: using the rotating wall vessel to study host-pathogen interactions. Nat Rev Microbiol, 8: 791-801.

Bernard HU, Burk RD, Chen Z, van Doorslaer K, zur Hausen H, de Villiers EM. 2010. Classification of papillomaviruses (PVs) based on 189 PV types and proposal of taxonomic amendments. Virology, 401: 70-79.

Berto A, Van der Poel WH, Hakze-van der Honing R, Martelli F, La Ragione RM, Inglese N, Collins J, Grierson S, Johne R, Reetz J, Dastjerdi A, Banks M. 2013. Replication of hepatitis E virus in three-dimensional cell culture. J Virol Methods, 187: 327-332.

Borgogna C, Zavattaro E, De Andrea M, Griffin HM, Dell'Oste V, Azzimonti B, Landini MM, Peh WL, Pfister H, Doorbar J, Landolfo S, Gariglio M. 2012. Characterization of beta papillomavirus E4 expression in tumours from Epidermodysplasia Verruciformis patients and in experimental models. Virology, 423: 195-204.

Bowser BS, Chen HS, Conway MJ, Christensen ND, Meyers C. 2011. Human papillomavirus type 18 chimeras containing the L2/L1 capsid genes from evolutionarily diverse papillomavirus types generate infectious virus. Virus Res, 160: 246-255.

Breslin S, O'Driscoll L. 2013. Three-dimensional cell culture: the missing link in drug discovery. Drug Discov Today, 18: 240 249.

Cerwinka WH, Sharp SM, Boyan BD, Zhau HE, Chung LW, Yates C. 2012. Differentiation of human mesenchymal stem cell spheroids under microgravity conditions. Cell Regen (Lond), 1: 2.

Cho NJ, Elazar M, Xiong A, Lee W, Chiao E, Baker J, Frank CW, Glenn JS. 2009. Viral infection of human progenitor and liverderived cells encapsulated in three-dimensional PEG-based hydrogel. Biomed Mater, 4: 011001.

Choi DJ, Choi SM, Kang HY, Min HJ, Lee R, Ikram M, Subhan F, Jin SW, Jeong YH, Kwak JY, Yoon S. 2015. Bioactive fish collagen/polycaprolactone composite nanofibrous scaffolds fabricated by electrospinning for 3D cell culture. J Biotechnol, 205: 47-58.

Choo QL, Kuo G, Weiner AJ, Overby LR, Bradley DW, Houghton M. 1989. Isolation of a cDNA clone derived from a blood-borne non-A, non-B viral hepatitis genome. Science, 244: 359-362.
Chow LT. 2015. Model systems to study the life cycle of human papillomaviruses and HPV-associated cancers. Virol Sin, 30: 92-100.

Chow LT, Duffy AA, Wang HK, Broker TR. 2009. A highly efficient system to produce infectious human papillomavirus: Elucidation of natural virus-host interactions. Cell Cycle, 8: 1319-1323.

Chung BG, Lee KH, Khademhosseini A, Lee SH. 2012. Microfluidic fabrication of microengineered hydrogels and their application in tissue engineering. Lab Chip, 12: 45-59.

Cox AL. 2015. MEDICINE. Global control of hepatitis C virus. Science, 349: 790-791.

Cukierman E, Pankov R, Yamada KM. 2002. Cell interactions with three-dimensional matrices. Curr Opin Cell Biol, 14: 633-639.

Dash P, Barnett PV, Denyer MS, Jackson T, Stirling CM, Hawes PC, Simpson JL, Monaghan P, Takamatsu HH. 2010. Foot-andmouth disease virus replicates only transiently in well-differentiated porcine nasal epithelial cells. J Virol, 84: 9149-9160.

De Clercq E. 2007. The design of drugs for HIV and HCV. Nat Rev Drug Discov, 6: 1001-1018.

Doorbar J. 2016. Model systems of human papillomavirus-associated disease. J Pathol, 238: 166-179.

Doorbar J, Quint W, Banks L, Bravo IG, Stoler M, Broker TR, Stanley MA. 2012. The biology and life-cycle of human papillomaviruses. Vaccine, 30 Suppl 5: F55-F70.

Edmondson R, Broglie JJ, Adcock AF, Yang L. 2014. Three-dimensional cell culture systems and their applications in drug discovery and cell-based biosensors. Assay Drug Dev Technol, 12: $207-218$.

Ettayebi K, Crawford SE, Murakami K, Broughman JR, Karandikar U, Tenge VR, Neill FH, Blutt SE, Zeng XL, Qu L, Kou B, Opekun AR, Burrin D, Graham DY, Ramani S, Atmar RL, Estes MK. 2016. Replication of human noroviruses in stem cell-derived human enteroids. Science, 353: 1387-1393.

Fang L, Meyers C, Budgeon LR, Howett MK. 2006. Induction of productive human papillomavirus type 11 life cycle in epithelial cells grown in organotypic raft cultures. Virology, 347: 2835.

Fotheringham JA, Raab-Traub N. 2013. Epstein-Barr virus latent membrane protein 2 effects on epithelial acinus development reveal distinct requirements for the PY and YEEA motifs. J Virol, 87: 13803-13815.

Frey O, Misun PM, Fluri DA, Hengstler JG, Hierlemann A. 2014. Reconfigurable microfluidic hanging drop network for multitissue interaction and analysis. Nat Commun, 5: 4250.

Friedl P, Alexander S. 2011. Cancer invasion and the microenvironment: plasticity and reciprocity. Cell, 147: 992-1009.

Friedl P, Sahai E, Weiss S, Yamada KM. 2012. New dimensions in cell migration. Nat Rev Mol Cell Biol, 13: 743-747.

Ghosh S, Spagnoli GC, Martin I, Ploegert S, Demougin P, Heberer M, Reschner A. 2005. Three-dimensional culture of melanoma cells profoundly affects gene expression profile: a high density oligonucleotide array study. J Cell Physiol, 204: 522-531.

Goodwin TJ, Jessup JM, Wolf DA. 1992. Morphologic differentiation of colon carcinoma cell lines HT-29 and HT-29KM in rotating-wall vessels. In Vitro Cell Dev Biol, 28A: 47-60.

Goodwin TJ, McCarthy M, Cohrs RJ, Kaufer BB. 2015. 3D tissuelike assemblies: A novel approach to investigate virus-cell interactions. Methods, 90: 76-84.

Goodwin TJ, McCarthy M, Osterrieder N, Cohrs RJ, Kaufer BB. 2013. Three-dimensional normal human neural progenitor tissue-like assemblies: a model of persistent varicella-zoster virus infection. PLoS Pathog, 9: e1003512. 
Goodwin TJ, Prewett TL, Wolf DA, Spaulding GF. 1993. Reduced shear stress: a major component in the ability of mammalian tissues to form three-dimensional assemblies in simulated microgravity. J Cell Biochem, 51: 301-311.

Griffith LG, Swartz MA. 2006. Capturing complex 3D tissue physiology in vitro. Nat Rev Mol Cell Biol, 7: 211-224.

Grill J, Lamfers ML, van Beusechem VW, Dirven CM, Pherai DS, Kater M, Van der Valk P, Vogels R, Vandertop WP, Pinedo HM, Curiel DT, Gerritsen WR. 2002. The organotypic multicellular spheroid is a relevant three-dimensional model to study adenovirus replication and penetration in human tumors in vitro. Mol Ther, 6: 609-614.

Grinnell F, Petroll WM. 2010. Cell motility and mechanics in three-dimensional collagen matrices. Annu Rev Cell Dev Biol, 26: 335-361.

Guilak F, Cohen DM, Estes BT, Gimble JM, Liedtke W, Chen CS. 2009. Control of stem cell fate by physical interactions with the extracellular matrix. Cell Stem Cell, 5: 17-26.

Gunatillake PA, Adhikari R. 2003. Biodegradable synthetic polymers for tissue engineering. Eur Cell Mater, 5: 1-16

Haisler WL, Timm DM, Gage JA, Tseng H, Killian TC, Souza GR. 2013. Three-dimensional cell culturing by magnetic levitation. Nat Protoc, 8: 1940-1949.

Hamilton G. 1998. Multicellular spheroids as an in vitro tumor model. Cancer Lett, 131: 29-34.

Hammond TG, Hammond JM. 2001. Optimized suspension culture: the rotating-wall vessel. Am J Physiol Renal Physiol, 281: F12-F25.

Haycock JW. 2010. In: 3D Cell Culture Methods and Protocols. New York: Humana Press.

Heesterbeek H, Anderson RM, Andreasen V, Bansal S, De Angelis D, Dye C, Eames KT, Edmunds WJ, Frost SD, Funk S, Hollingsworth TD, House T, Isham V, Klepac P, Lessler J, Lloyd-Smith JO, Metcalf CJ, Mollison D, Pellis L, Pulliam JR, Roberts MG, Viboud C, Isaac Newton Institute IDDC. 2015. Modeling infectious disease dynamics in the complex landscape of global health. Science, 347: aaa4339.

Heininger U, Seward JF. 2006. Varicella. Lancet, 368: 1365-1376.

Hermonat PL, You H, Chiriva-Internati CM, Liu Y. 2005. Analysis of adeno-associated virus and HPV interaction. Methods Mol Med, 119: 397-409.

Heymann DL, Chen L, Takemi K, Fidler DP, Tappero JW, Thomas MJ, Kenyon TA, Frieden TR, Yach D, Nishtar S, Kalache A, Olliaro PL, Horby P, Torreele E, Gostin LO, Ndomondo-Sigonda M, Carpenter D, Rushton S, Lillywhite L, Devkota B, Koser K, Yates R, Dhillon RS, Rannan-Eliya RP. 2015. Global health security: the wider lessons from the west African Ebola virus disease epidemic. Lancet, 385: 1884-1901.

Hjelm BE, Berta AN, Nickerson CA, Arntzen CJ, HerbstKralovetz MM. 2010. Development and characterization of a three-dimensional organotypic human vaginal epithelial cell model. Biol Reprod, 82: 617-627.

Huang GY, Zhou LH, Zhang QC, Chen YM, Sun W, Xu F, Lu TJ. 2011. Microfluidic hydrogels for tissue engineering. Biofabrication, 3: 012001.

Hukkanen V, Mikola H, Nykanen M, Syrjanen S. 1999. Herpes simplex virus type 1 infection has two separate modes of spread in three-dimensional keratinocyte culture. J Gen Virol, 80: 2149-2155.

Hutmacher DW. 2010. Biomaterials offer cancer research the third dimension. Nat Mater, 9: 90-93.

Israr M, Mitchell D, Alam S, Dinello D, Kishel JJ, Meyers C. 2010. Effect of the HIV protease inhibitor amprenavir on the growth and differentiation of primary gingival epithelium. Antivir Ther, 15: 253-265.
Israr M, Mitchell D, Alam S, Dinello D, Kishel JJ, Meyers C. 2011. The HIV protease inhibitor lopinavir/ritonavir (Kaletra) alters the growth, differentiation and proliferation of primary gingival epithelium. HIV Med, 12: 145-156.

Kapikian AZ, Wyatt RG, Dolin R, Thornhill TS, Kalica AR, Chanock RM. 1972. Visualization by immune electron microscopy of a 27-nm particle associated with acute infectious nonbacterial gastroenteritis. J Virol, 10: 1075-1081.

Karlsson H, Fryknas M, Larsson R, Nygren P. 2012. Loss of cancer drug activity in colon cancer HCT-116 cells during spheroid formation in a new 3-D spheroid cell culture system. Exp Cell Res, 318: 1577-1585.

Kawada M, Nagamori S, Aizaki H, Fukaya K, Niiya M, Matsuura T, Sujino H, Hasumura S, Yashida H, Mizutani S, Ikenaga H. 1998. Massive culture of human liver cancer cells in a newly developed radial flow bioreactor system: ultrafine structure of functionally enhanced hepatocarcinoma cell lines. In Vitro Cell Dev Biol Anim, 34: 109-115.

Keane TJ, Badylak SF. 2014. Biomaterials for tissue engineering applications. Semin Pediatr Surg, 23: 112-118.

Kelm JM, Timmins NE, Brown CJ, Fussenegger M, Nielsen LK. 2003. Method for generation of homogeneous multicellular tumor spheroids applicable to a wide variety of cell types. Biotechnol Bioeng, 83: 173-180.

Kim JA, Choi JH, Kim M, Rhee WJ, Son B, Jung HK, Park TH. 2013. High-throughput generation of spheroids using magnetic nanoparticles for three-dimensional cell culture. Biomaterials, 34: 8555-8563.

Kim JB. 2005. Three-dimensional tissue culture models in cancer biology. Semin Cancer Biol, 15: 365-377.

Kleinman HK, Martin GR. 2005. Matrigel: basement membrane matrix with biological activity. Semin Cancer Biol, 15: 378 386.

Lam TT, Wang J, Shen Y, Zhou B, Duan L, Cheung CL, Ma C, Lycett SJ, Leung CY, Chen X, Li L, Hong W, Chai Y, Zhou L, Liang H, Ou Z, Liu Y, Farooqui A, Kelvin DJ, Poon LL, Smith DK, Pybus OG, Leung GM, Shu Y, Webster RG, Webby RJ, Peiris JS, Rambaut A, Zhu H, Guan Y. 2013. The genesis and source of the H7N9 influenza viruses causing human infections in China. Nature, 502: 241-244.

Lam V, Bigley T, Terhune SS, Wakatsuki T. 2012. A method for quantifying mechanical properties of tissue following viral infection. PLoS One, 7: e42197.

Lee J, Cuddihy MJ, Kotov NA. 2008. Three-dimensional cell culture matrices: state of the art. Tissue Eng Part B Rev, 14: 61-86.

Lee J, Lee S, Roh K, Jung E, Park D. 2015. A novel culture system to induce melanin synthesis by three-dimensional spheroid culture. Biotechnology and Bioprocess Engineering, 20: 194-200.

Lessler J, Chaisson LH, Kucirka LM, Bi Q, Grantz K, Salje H, Carcelen AC, Ott CT, Sheffield JS, Ferguson NM, Cummings DA, Metcalf CJ, Rodriguez-Barraquer I. 2016. Assessing the global threat from Zika virus. Science, 353: aaf8160.

Li Z, Cui Z. 2014. Three-dimensional perfused cell culture. Biotechnol Adv, 32: 243-254.

Lin RZ, Chang HY. 2008. Recent advances in three-dimensional multicellular spheroid culture for biomedical research. Biotechnol J, 3: 1172-1184.

Lindenbach BD, Evans MJ, Syder AJ, Wolk B, Tellinghuisen TL, Liu CC, Maruyama T, Hynes RO, Burton DR, McKeating JA, Rice CM. 2005. Complete replication of hepatitis $\mathrm{C}$ virus in cell culture. Science, 309: 623-626.

Liu S, Chen R, Hagedorn CH. 2014. Direct visualization of hepatitis $\mathrm{C}$ virus-infected Huh7.5 cells with a high titre of infectious chimeric JFH1-EGFP reporter virus in three-dimensional Matri- 
gel cell cultures. J Gen Virol, 95: 423-433.

Loessner D, Stok KS, Lutolf MP, Hutmacher DW, Clements JA, Rizzi SC. 2010. Bioengineered 3D platform to explore cellECM interactions and drug resistance of epithelial ovarian cancer cells. Biomaterials, 31: 8494-8506.

Long JP, Pierson S, Hughes JH. 1998. Rhinovirus replication in HeLa cells cultured under conditions of simulated microgravity. Aviat Space Environ Med, 69: 851-856.

Louz D, Bergmans HE, Loos BP, Hoeben RC. 2013. Animal models in virus research: their utility and limitations. Crit Rev Microbiol, 39: 325-361.

Lutolf MP, Hubbell JA. 2005. Synthetic biomaterials as instructive extracellular microenvironments for morphogenesis in tissue engineering. Nat Biotechnol, 23: 47-55.

Maartens G, Celum C, Lewin SR. 2014. HIV infection: epidemiology, pathogenesis, treatment, and prevention. Lancet, 384 : 258-271.

Madsen CD, Sahai E. 2010. Cancer dissemination--lessons from leukocytes. Dev Cell, 19: 13-26.

Malik H, Khan FH, Ahsan H. 2014. Human papillomavirus: current status and issues of vaccination. Arch Virol, 159: 199-205.

Margolis LB, Fitzgerald W, Glushakova S, Hatfill S, Amichay N, Baibakov B, Zimmerberg J. 1997. Lymphocyte trafficking and HIV infection of human lymphoid tissue in a rotating wall vessel bioreactor. AIDS Res Hum Retroviruses, 13: 1411-1420.

Mazzoleni G, Di Lorenzo D, Steimberg N. 2009. Modelling tissues in 3D: the next future of pharmaco-toxicology and food research? Genes Nutr, 4: 13-22.

McGuigan C, Pathirana RN, Migliore M, Adak R, Luoni G, Jones AT, Diez-Torrubia A, Camarasa MJ, Velazquez S, Henson G, Verbeken E, Sienaert R, Naesens L, Snoeck R, Andrei G, Balzarini J. 2007. Preclinical development of bicyclic nucleoside analogues as potent and selective inhibitors of varicella zoster virus. J Antimicrob Chemother, 60: 1316-1330.

McLaughlin-Drubin ME, Christensen ND, Meyers C. 2004. Propagation, infection, and neutralization of authentic HPV16 virus. Virology, 322: 213-219.

McLaughlin-Drubin ME, Meyers C. 2005. Propagation of infectious, high-risk HPV in organotypic "raft" culture. Methods Mol Med, 119: 171-186.

McLaughlin-Drubin ME, Wilson S, Mullikin B, Suzich J, Meyers C. 2003 . Human papillomavirus type 45 propagation, infection, and neutralization. Virology, 312: 1-7.

Meyers C, Andreansky SS, Courtney RJ. 2003. Replication and interaction of herpes simplex virus and human papillomavirus in differentiating host epithelial tissue. Virology, 315: 43-55.

Meyers C, Bromberg-White JL, Zhang J, Kaupas ME, Bryan JT, Lowe RS, Jansen KU. 2002. Infectious virions produced from a human papillomavirus type 18/16 genomic DNA chimera. J Virol, 76: 4723-4733.

Meyers C, Frattini MG, Hudson JB, Laimins LA. 1992. Biosynthesis of human papillomavirus from a continuous cell line upon epithelial differentiation. Science, 257: 971-973.

Mihalcin M, Polak P, Husa P. 2015. Hepatitis E--overview of the latest knowledge. Epidemiol Mikrobiol Imunol, 64: 72-78. (In Czech)

Mitchell D, Israr M, Alam S, Dinello D, Kishel J, Jia R, Meyers C. 2014. HIV nucleoside reverse transcriptase inhibitors efavirenz and tenofovir change the growth and differentiation of primary gingival epithelium. HIV Med, 15: 196-202.

Mitchell D, Israr M, Alam S, Kishel J, Dinello D, Meyers C. 2012. Effect of the HIV nucleoside reverse transcriptase inhibitor zidovudine on the growth and differentiation of primary gingival epithelium. HIV Med, 13: 276-290.
Mole S, McFarlane M, Chuen-Im T, Milligan SG, Millan D, Graham SV. 2009. RNA splicing factors regulated by HPV16 during cervical tumour progression. J Pathol, 219: 383-391.

Molina-Jimenez F, Benedicto I, Dao Thi VL, Gondar V, Lavillette D, Marin JJ, Briz O, Moreno-Otero R, Aldabe R, Baumert TF, Cosset FL, Lopez-Cabrera M, Majano PL. 2012. Matrigelembedded 3D culture of Huh-7 cells as a hepatocyte-like polarized system to study hepatitis $\mathrm{C}$ virus cycle. Virology, 425: 31-39.

Moore PS, Chang Y. 2010. Why do viruses cause cancer? Highlights of the first century of human tumour virology. Nat Rev Cancer, 10: 878-889.

Morens DM, Folkers GK, Fauci AS. 2004. The challenge of emerging and re-emerging infectious diseases. Nature, 430: 242-249.

Murakami K, Inoue Y, Hmwe SS, Omata K, Hongo T, Ishii K, Yoshizaki S, Aizaki H, Matsuura T, Shoji I, Miyamura T, Suzuki T. 2008. Dynamic behavior of hepatitis $\mathrm{C}$ virus quasispecies in a long-term culture of the three-dimensional radial-flow bioreactor system. J Virol Methods, 148: 174-181.

Murakami K, Ishii K, Ishihara Y, Yoshizaki S, Tanaka K, Gotoh Y, Aizaki H, Kohara M, Yoshioka H, Mori Y, Manabe N, Shoji I, Sata T, Bartenschlager R, Matsuura Y, Miyamura T, Suzuki T. 2006. Production of infectious hepatitis $C$ virus particles in three-dimensional cultures of the cell line carrying the genomelength dicistronic viral RNA of genotype 1b. Virology, 351: 381-392.

Nickerson CA, Ott CM, Wilson JW, Ramamurthy R, Pierson DL. 2004. Microbial responses to microgravity and other low-shear environments. Microbiol Mol Biol Rev, 68: 345-361.

Nickerson CA, Richter EG, Ott CM. 2007. Studying host-pathogen interactions in 3-D: organotypic models for infectious disease and drug development. J Neuroimmune Pharmacol, 2: 26-31.

Nicoll MP, Proenca JT, Efstathiou S. 2012. The molecular basis of herpes simplex virus latency. FEMS Microbiol Rev, 36: 684705.

Noya F, Balague C, Banerjee NS, Curiel DT, Broker TR, Chow LT. 2003. Activation of adenovirus early promoters and lytic phase in differentiated strata of organotypic cultures of human keratinocytes. J Virol, 77: 6533-6540.

Osterman A, Stellberger T, Gebhardt A, Kurz M, Friedel CC, Uetz P, Nitschko H, Baiker A, Vizoso-Pinto MG. 2015. The Hepatitis E virus intraviral interactome. Sci Rep, 5: 13872.

Ozbun MA. 2002. Infectious human papillomavirus type $31 \mathrm{~b}$ : purification and infection of an immortalized human keratinocyte cell line. J Gen Virol, 83: 2753-2763.

Ozbun MA, Patterson NA. 2014. Using organotypic (raft) epithelial tissue cultures for the biosynthesis and isolation of infectious human papillomaviruses. Curr Protoc Microbiol, 34. doi: 10.1002/9780471729259.mc14b03s34.

Page H, Flood P, Reynaud EG. 2013. Three-dimensional tissue cultures: current trends and beyond. Cell Tissue Res, 352: 123-131.

Pampaloni F, Reynaud EG, Stelzer EH. 2007. The third dimension bridges the gap between cell culture and live tissue. Nat Rev Mol Cell Biol, 8: 839-845.

Papafragkou E, Hewitt J, Park GW, Greening G, Vinje J. 2014. Challenges of culturing human norovirus in three-dimensional organoid intestinal cell culture models. PLoS One, 8: e63485.

Petrie RJ, Gavara N, Chadwick RS, Yamada KM. 2012. Nonpolarized signaling reveals two distinct modes of $3 \mathrm{D}$ cell migration. $\mathrm{J}$ Cell Biol, 197: 439-455.

Petrie RJ, Yamada KM. 2012. At the leading edge of three-dimensional cell migration. J Cell Sci, 125: 5917-5926. 
Poynard T, Yuen MF, Ratziu V, Lai CL. 2003. Viral hepatitis C. Lancet, 362: 2095-2100.

Rajalakshmy AR, Malathi J, Madhavan HN, Samuel JK. 2015. Mebiolgel, a thermoreversible polymer as a scaffold for three dimensional culture of Huh7 cell line with improved hepatocyte differentiation marker expression and HCV replication. Indian J Med Microbiol, 33: 554-559.

Ravi M, Paramesh V, Kaviya SR, Anuradha E, Solomon FD. 2015. 3D cell culture systems: advantages and applications. J Cell Physiol, 230: 16-26.

Rhee HW, Zhau HE, Pathak S, Multani AS, Pennanen S, Visakorpi T, Chung LW. 2001. Permanent phenotypic and genotypic changes of prostate cancer cells cultured in a three-dimensional rotating-wall vessel. In Vitro Cell Dev Biol Anim, 37: 127-140.

Richard C, Lanner C, Naryzhny SN, Sherman L, Lee H, Lambert PF, Zehbe I. 2010. The immortalizing and transforming ability of two common human papillomavirus 16 E6 variants with different prevalences in cervical cancer. Oncogene, 29: 34353445.

Robinson CM, Pfeiffer JK. 2014. Virology. Leaping the norovirus hurdle. Science, 346: 700-701.

Ruedinger F, Lavrentieva A, Blume C, Pepelanova I, Scheper T. 2015. Hydrogels for 3D mammalian cell culture: a starting guide for laboratory practice. Appl Microbiol Biotechnol, 99: 623-636.

Sainz B, Jr., Barretto N, Uprichard SL. 2009a. Hepatitis C virus infection in phenotypically distinct Huh7 cell lines. PLoS One, 4: e6561.

Sainz B, Jr., TenCate V, Uprichard SL. 2009b. Three-dimensional Huh7 cell culture system for the study of Hepatitis $C$ virus infection. Virol J, 6: 103.

Samuelson L, Gerber DA. 2013. Improved function and growth of pancreatic cells in a three-dimensional bioreactor environment. Tissue Eng Part C Methods, 19: 39-47.

Satsuka A, Yoshida S, Kajitani N, Nakamura H, Sakai H. 2010. Novel human papillomavirus type 18 replicon and its application in screening the antiviral effects of cytokines. Cancer Sci, 101: 536-542.

Saxena K, Blutt SE, Ettayebi K, Zeng XL, Broughman JR, Crawford SE, Karandikar UC, Sastri NP, Conner ME, Opekun AR, Graham DY, Qureshi W, Sherman V, Foulke-Abel J, In J, Kovbasnjuk O, Zachos NC, Donowitz M, Estes MK. 2015. Human intestinal enteroids: a new model to study human rotavirus infection, host restriction, and pathophysiology. J Virol, 90: 43-56.

Schiffman M, Castle PE, Jeronimo J, Rodriguez AC, Wacholder S. 2007. Human papillomavirus and cervical cancer. Lancet, 370 : 890-907.

Souza GR, Molina JR, Raphael RM, Ozawa MG, Stark DJ, Levin CS, Bronk LF, Ananta JS, Mandelin J, Georgescu MM, Bankson JA, Gelovani JG, Killian TC, Arap W, Pasqualini R. 2010. Three-dimensional tissue culture based on magnetic cell levitation. Nat Nanotechnol, 5: 291-296.

Straub TM, Bartholomew RA, Valdez CO, Valentine NB, Dohnalkova A, Ozanich RM, Bruckner-Lea CJ, Call DR. 2011. Human norovirus infection of caco-2 cells grown as a three-dimensional tissue structure. J Water Health, 9: 225-240.

Straub TM, Honer zu Bentrup K, Orosz-Coghlan P, Dohnalkova A, Mayer BK, Bartholomew RA, Valdez CO, Bruckner-Lea CJ, Gerba CP, Abbaszadegan M, Nickerson CA. 2007. In vitro cell culture infectivity assay for human noroviruses. Emerg Infect Dis, 13: 396-403.
Syrjanen S, Mikola H, Nykanen M, Hukkanen V. 1996. In vitro establishment of lytic and nonproductive infection by herpes simplex virus type 1 in three-dimensional keratinocyte culture. J Virol, 70: 6524-6528.

Tan M, Jiang X. 2014. Vaccine against norovirus. Hum Vaccin Immunother, 10: 1449-1456.

Tapparel C, Sobo K, Constant S, Huang S, Van Belle S, Kaiser L. 2013. Growth and characterization of different human rhinovirus $\mathrm{C}$ types in three-dimensional human airway epithelia reconstituted in vitro. Virology, 446: 1-8.

Team WHOER. 2014. Ebola virus disease in West Africa--the first 9 months of the epidemic and forward projections. N Engl J Med, 371: 1481-1495.

Tran NM, Dufresne M, Duverlie G, Castelain S, Defarge C, Paullier P, Legallais C. 2013. An appropriate selection of a 3D alginate culture model for hepatic Huh-7 cell line encapsulation intended for viral studies. Tissue Eng Part A, 19: 103-113.

Trietsch SJ, Israels GD, Joore J, Hankemeier T, Vulto P. 2013. Microfluidic titer plate for stratified 3D cell culture. Lab Chip, 13: $3548-3554$

Tseng H, Gage JA, Raphael RM, Moore RH, Killian TC, GrandeAllen KJ, Souza GR. 2013. Assembly of a three-dimensional multitype bronchiole coculture model using magnetic levitation. Tissue Eng Part C Methods, 19: 665-675.

Unsworth BR, Lelkes PI. 1998. Growing tissues in microgravity. Nat Med, 4: 901-907.

van Duinen V, Trietsch SJ, Joore J, Vulto P, Hankemeier T. 2015. Microfluidic 3D cell culture: from tools to tissue models. Curr Opin Biotechnol, 35: 118-126.

Vinci M, Box C, Eccles SA. 2015. Three-dimensional (3D) tumor spheroid invasion assay. J Vis Exp: e52686.

Vinci M, Gowan S, Boxall F, Patterson L, Zimmermann M, Court W, Lomas C, Mendiola M, Hardisson D, Eccles SA. 2012. Advances in establishment and analysis of three-dimensional tumor spheroid-based functional assays for target validation and drug evaluation. BMC Biol, 10: 29.

Visalli RJ, Courtney RJ, Meyers C. 1997. Infection and replication of herpes simplex virus type 1 in an organotypic epithelial culture system. Virology, 230: 236-243.

Wang HK, Duffy AA, Broker TR, Chow LT. 2009. Robust production and passaging of infectious HPV in squamous epithelium of primary human keratinocytes. Genes Dev, 23: 181-194.

Wang N, Zhang H, Zhang BQ, Liu W, Zhang Z, Qiao M, Zhang H, Deng F, Wu N, Chen X, Wen S, Zhang J, Liao Z, Zhang Q, Yan Z, Yin L, Ye J, Deng Y, Luu HH, Haydon RC, Liang H, He TC. 2014. Adenovirus-mediated efficient gene transfer into cultured three-dimensional organoids. PLoS One, 9: e93608.

WHO 2013. Mortality and global health estimates 2013. Available: http://apps.who.int/gho/data/node.main.686?lang=en

Worthington P, Pochan DJ, Langhans SA. 2015. Peptide Hydrogels - Versatile Matrices for 3D Cell Culture in Cancer Medicine. Front Oncol, 5: 92.

Xu X, Farach-Carson MC, Jia X. 2014. Three-dimensional in vitro tumor models for cancer research and drug evaluation. Biotechnol Adv, 32: 1256-1268.

Yamada KM, Cukierman E. 2007. Modeling tissue morphogenesis and cancer in 3D. Cell, 130: 601-610

Zerboni L, Sen N, Oliver SL, Arvin AM. 2014. Molecular mechanisms of varicella zoster virus pathogenesis. Nat Rev Microbiol, 12: $197-210$.

Zhang W, Zhuang A, Gu P, Zhou H, Fan X. 2016. A review of the three-dimensional cell culture technique: Approaches, advantages and applications. Curr Stem Cell Res Ther, 11:370-380. 